\title{
EFFECTS OF THE EGG CYCLE AND ROUTE OF ADMINISTRATION ON PROSTAGLANDIN-INDUCED OVIPOSITION OF HENS AND JAPANESE QUAIL
}

\author{
F. HERTELENDY, H. V. BIELLIER* AND H. TODD \\ Departments of Medicine and Physiology, St Louis University School of Medicine, \\ St Louis, Missouri 63104, and *Department of Poultry Science, \\ University of Missouri, Columbia, Missouri 65201, U.S.A.
}

(Received 27th Fanuary 1975)

It is known that the oxytocin (vasotocin) response in the domestic hen varies during the period of a single egg cycle with a significant increase in sensitivity as the time of spontaneous oviposition approaches (Gilbert, 1971). In this respect, the avian shell gland is similar to the mammalian uterus.

We have reported previously that intrauterine injection of prostaglandins (PG) or essential fatty acids (which may serve as prostaglandin precursors) can induce premature oviposition in the domestic fowl (Hertelendy et al., 1974) and the japanese quail (Hertelendy, 1972, 1974). In these studies premature oviposition was induced when there was a hard egg in the uterus, but several hours before the anticipated spontaneous oviposition. The present report is of the response of the domestic fowl to $\mathrm{PGE}_{1}$ at two different stages of the egg cycle, and the effect of route of administration on the efficacy of $\mathrm{PGE}_{1}$ and $\mathrm{PGF}_{2 \alpha}$ in the Japanese quail (Coturnix coturnix japonica). In addition, we measured plasma progesterone levels in two groups of hens when there was either a soft or hard egg in the uterus in view of the well known inhibitory action of this steroid on the uterus of certain mammals (Reynolds \& Allen, 1932; Csapo, 1961).

White Leghorn hens were caged singly under a photoperiod of $14 \mathrm{hr}$ light/ $10 \mathrm{hr}$ dark. The time of oviposition was accurately determined by means of an electronic scanning device which recorded the presence of an egg in the cage every $15 \mathrm{~min}$. The presence of a hard or soft egg in the uterus was verified manually. Prostaglandins (Upjohn Co., Kalamazoo, Michigan) were freshly diluted with saline from ethanolic stock solutions (1 to $5 \mathrm{mg} / \mathrm{ml}$ ) and administered as indicated in the tables. Blood was collected from a wing vein into a heparinized syringe just before the injection of $\mathrm{PGE}_{1}$ for the induction of oviposition. After centrifugation, the plasma was removed and stored at $-20^{\circ} \mathrm{C}$ until analysis. Plasma progesterone was determined by radioimmunoassay developed for the estimation of progesterone in fowl plasma (Furr, 1973). Our results using this procedure are in good agreement with values reported by Furr (1973) and Furr et al. (1973).

Japanese quail were maintained and the stage of egg formation at the time of premature oviposition was estimated as previously described (Hertelendy, 
1972). Saline solution containing various amounts of $\mathrm{PGE}_{1}$ and $\mathrm{PGE}_{2}$ were administered by five different routes and the period between treatment and oviposition (induction time) was recorded.

Towards the end of the egg cycle ( 1 to $3 \mathrm{hr}$ before anticipated oviposition), when shell calcification is virtually complete, as little as $0.2 \mu \mathrm{g} \mathrm{PGE}_{1}$ injected into the uterus induced oviposition within a few minutes in all fifteen birds tested (Table 1). The efficacy of intravenous injection of $\mathrm{PGE}_{1}$ at the same stage in the egg cycle was less than $10 \%$ that given by the intrauterine route. When PGE $_{1}$ was given by the intrauterine route 15 to $18 \mathrm{hr}$ before the expected oviposition (when the egg is enclosed in membranes only without any appreciable deposits of $\mathrm{CaCO}_{3}$ ), only $1 / 6$ and $3 / 7$ hens responded to 0.2 and $0.4 \mu \mathrm{g}$ $\mathrm{PGE}_{1}$, respectively. Intravenous doses were similarly less effective and were inhibitory at levels over 3 to $4 \mu \mathrm{g}$ (Table 1). There appears to be a relationship between the efficacy of $\mathrm{PGE}_{1}$ and the degree of egg formation; the closer the time of spontaneous oviposition the more responsive the avian uterus seems to be to oxytocic compounds. The parturient human uterus is also more sensitive to prostaglandins than the pregnant one. The recommended intravenous infusion rate of $\mathrm{PGF}_{2 \alpha}$ and $\mathrm{PGE}_{2}$ for the induction of abortion is ten times greater than that recommended for induction of labour (Beazley, 1973).

Table 1. Induction of oviposition in the domestic hen by intrauterine and intravenous injection of $\mathrm{PGE}_{1}$ at different times of the egg cycle

\begin{tabular}{|c|c|c|c|c|c|c|}
\hline $\begin{array}{l}\text { Time before expected } \\
\text { oviposition }(h r)\end{array}$ & $\begin{array}{c}\text { Route of } \\
\text { administration }\end{array}$ & $\begin{array}{c}\text { Dose } \\
(\mu g / \text { bird })\end{array}$ & $\begin{array}{l}\text { No. of } \\
\text { tests }\end{array}$ & $\begin{array}{c}\text { No. of } \\
\text { premature } \\
\text { ovipositions }\end{array}$ & $\begin{array}{c}\text { Average } \\
\text { induction } \\
\text { time }(\min )\end{array}$ & $E g g$ \\
\hline $\begin{array}{c}1-3 \\
1-3 \\
15-18 \\
15-18 \\
15-18 \\
15-18 \\
15-18 \\
15-18 \\
15-18 \\
15-18\end{array}$ & $\begin{array}{l}\text { i.u. } \\
\text { i.v. } \\
\text { i.u. } \\
\text { i.u. } \\
\text { i.v. } \\
\text { i.v. } \\
\text { i.v. } \\
\text { i.v. } \\
\text { i.v. } \\
\text { i.v. }\end{array}$ & $\begin{array}{r}0.2 \\
2 \cdot 0 \\
0.2 \\
0.4 \\
1.0 \\
2.0 \\
3.0 \\
4.0 \\
5.0 \\
10.0\end{array}$ & $\begin{array}{r}15 \\
17 \\
6 \\
7 \\
6 \\
11 \\
16 \\
16 \\
8 \\
11\end{array}$ & $\begin{array}{r}15 \\
11 \\
1 \\
3 \\
0 \\
2 \\
6 \\
5 \\
1 \\
0\end{array}$ & $\begin{array}{l}6 \cdot 9 \\
9 \cdot 7 \\
5 \cdot 7 \\
7 \cdot 0 \\
9 \cdot 5 \\
6 \cdot 7 \\
8 \cdot 0 \\
7 \cdot 0 \\
-\end{array}$ & $\begin{array}{l}\text { Hard } \\
\text { Hard } \\
\text { Soft } \\
\text { Soft } \\
\text { Soft } \\
\text { Soft } \\
\text { Soft } \\
\text { Soft } \\
-\end{array}$ \\
\hline
\end{tabular}

i.u. = intrauterine; i.v. = intravenous.

Plasma progesterone values (mean \pm S.E.) were significantly $(P<0.001)$ higher when there was a hard egg in the uterus $(8.0 \pm 1.01 \mathrm{ng} / \mathrm{ml}$, thirteen birds), compared to values obtained with a soft egg $(3.49 \pm 0.52 \mathrm{ng} / \mathrm{ml}$, fourteen birds) or no egg (3.50 $\pm 0.67 \mathrm{ng} / \mathrm{ml}$, five birds) in the oviduct. Higher peripheral levels of progesterone do not seem, therefore, to be responsible for the reduced response to $\mathrm{PGE}_{1}$ administration. Peak levels of circulating progesterone in the laying hen have been reported to occur at 5 to $6 \mathrm{hr}$ before ovulation (Peterson \& Common, 1971; Kappauf \& van Tienhoven, 1972; Furr et al., 1973), which normally takes place within $30 \mathrm{~min}$ after oviposition. Other investigators have found a progesterone peak 2 to $4 \mathrm{hr}$ before oviposition (Arcos \& Opel, 1971). 
This rise in circulating levels of progesterone may be involved in triggering the LH release that precedes ovulation (Fraps, 1961). Furr et al. (1973) measured progesterone and $\mathrm{LH}$ at frequent intervals during the laying cycle and observed a simultaneous rise in plasma levels of these two hormones 4 to $7 \mathrm{hr}$ before ovulation. Oestradiol has also been implicated in the mechanism of $\mathrm{LH}$ release (Senior \& Cunningham, 1974). Although the cause or purpose for this rise in plasma progesterone remains uncertain, it does not appear to be associated with uterine activity and oviposition.

Table 2. Effect of route of administration on the induction of oviposition by $\mathrm{PGE}_{1}$ and $\mathrm{PGF}_{2 \alpha}$ in Japanese quail

\begin{tabular}{|c|c|c|c|c|c|}
\hline $\begin{array}{c}\text { Route of } \\
\text { administration }\end{array}$ & Prostaglandin & $\begin{array}{c}\text { Dose } \\
(\mu g / \text { bird })\end{array}$ & $\begin{array}{l}\text { No. of } \\
\text { tests }\end{array}$ & $\begin{array}{c}\text { No. of } \\
\text { premature } \\
\text { ovipositions }\end{array}$ & $\begin{array}{c}\text { Average } \\
\text { induction } \\
\text { time }(\min )\end{array}$ \\
\hline Intrauterine & $\begin{array}{l}E_{1} \\
E_{1} \\
F_{2 \alpha}\end{array}$ & $\begin{array}{l}0.1 \\
0.01 \\
1.0\end{array}$ & $\begin{array}{r}10 \\
7 \\
9\end{array}$ & $\begin{array}{r}10 \\
5 \\
7\end{array}$ & $\begin{array}{r}3 \cdot 6 \\
3 \cdot 8 \\
21 \cdot 5\end{array}$ \\
\hline Intravenous & $\begin{array}{l}E_{1} \\
E_{1} \\
F_{2 \alpha}\end{array}$ & $\begin{array}{l}1 \cdot 0 \\
0 \cdot 5 \\
2 \cdot 5\end{array}$ & $\begin{array}{r}5 \\
10 \\
12\end{array}$ & $\begin{array}{l}5 \\
2 \\
3\end{array}$ & $\begin{array}{l}1 \cdot 8 \\
3 \cdot 0 \\
4 \cdot 3\end{array}$ \\
\hline Intramuscular & $\begin{array}{l}\mathrm{E}_{1} \\
\mathrm{E}_{1} \\
\mathrm{~F}_{2 \alpha}\end{array}$ & $\begin{array}{l}2 \cdot 0 \\
1 \cdot 0 \\
5 \cdot 0\end{array}$ & $\begin{array}{r}10 \\
11 \\
6\end{array}$ & $\begin{array}{l}4 \\
3 \\
4\end{array}$ & $\begin{array}{r}5 \cdot 5 \\
11 \cdot 3 \\
8 \cdot 5\end{array}$ \\
\hline Intraperitoneal & $\begin{array}{l}\mathrm{E}_{1} \\
\mathrm{E}_{1} \\
\mathrm{~F}_{2 \alpha}\end{array}$ & $\begin{array}{l}2 \cdot 0 \\
1 \cdot 0 \\
5 \cdot 0\end{array}$ & $\begin{array}{r}8 \\
8 \\
10\end{array}$ & $\begin{array}{l}5 \\
3 \\
5\end{array}$ & $\begin{array}{r}13 \cdot 4 \\
22 \cdot 7 \\
4 \cdot 6\end{array}$ \\
\hline Oral & $\begin{array}{l}E_{1} \\
E_{1} \\
F_{2 \alpha}\end{array}$ & $\begin{array}{l}20.0 \\
10.0 \\
10.0\end{array}$ & $\begin{array}{r}3 \\
13 \\
6\end{array}$ & $\begin{array}{l}1 \\
1 \\
1\end{array}$ & $\begin{array}{r}13.0 \\
8.0 \\
5.0\end{array}$ \\
\hline
\end{tabular}

The results summarizing the efficacy of prostaglandins administered by various different routes (Table 2) are in general agreement with data obtained in humans (Karim, 1971), the direct intrauterine approach being the most effective and the oral the least. Studies designed to clarify the possible physiological role of prostaglandins in oviposition in birds are in progress.

We are grateful to Dr B. J. Furr, I.C.I. Pharmaceuticals Division, Alderley Park, Cheshire, for the anti-progesterone serum and to Dr J. Pike, Upjohn Co., Kalamazoo, Michigan, for the prostaglandins.

\section{REFERENGES}

ARcos, M. \& OpEL, H. (1971) Plasma progesterone in the hen during the ovulation cycle. Endocrinology 88, (Suppl.), 1-164.

Beazley, J.M. (1973) Treatment with prostaglandins. Clinics Endocr. Metab. 2, 411-422.

Csapo, A. (1961) Defence mechanism of pregnancy. In Progesterone and the Defence Mechanism of Pregnancy, Ciba Fndn Study Group, 9, pp. 3-31. Eds G. E. W. Wolstenholme \& M. T. Cameron. Churchill, London.

Fraps, R.M. (1961) Ovulation in the domestic fowl. In Control of Ovulation, pp. 135-167. Ed. C. A. Villee. Pergamon Press, New York. 
FURR, B.J.A. (1973) Radioimmunoassay of progesterone in peripheral plasma of the domestic fowl in various physiological states and in follicular venous plasma. Acta endocr., Copenh. 72, 89-100.

Furr, B.J.A., Bonney, R.C., England, R. J. \& Gunningham, F.J. (1973) Luteinizing hormone and progesterone in peripheral blood during the ovulatory cycle of the hen, Gallus domesticus. $\mathcal{J}$. Endocr. 57, 159-169.

Grrberr, A.B. (1971) Transport of the egg through the oviduct and oviposition. In Physiology and Biochemistry of the Domestic Fowl, pp. 1345-1352. Eds D. J. Bell \& B. M. Freeman. Academic Press, London.

Hertelendy, F. (1972) Prostaglandin-induced premature oviposition in the coturnix quail. Prostaglandins 2, 269-279.

Hertelendy, F. (1974) Effects of prostaglandins, cyclic AMP, seminal plasma, indomethacin, and other factors on oviposition in the Japanese quail, Coturnix coturnix japonica. F. Reprod. Fert. 40, 8793.

Hertelendy, F., Yeh, M. \& Biellier, H.V. (1974) Induction of oviposition in the domestic hen by prostaglandins. Gen. comp. Endocr. 22, 529-531.

Kappauf, B. \& van Tienhoven, A. (1972) Progesterone concentrations in peripheral plasma of laying hens in relation to the time of ovulation. Endocrinology 90, 1350-1355.

Karim, S. (1971) Action of prostaglandin in the pregnant woman. Ann. N.Y. Acad. Sci. 180, 483-498.

Peterson, A.J. \& Common, R.H. (1971) Progesterone concentration in the peripheral plasma of laying hens as determined by competitive protein binding assay. Can. 7. Zool. 49, 599-604.

Reynolds, S.R.M. \& Allen, W.M. (1932) The effect of progesterone-containing extracts of corpora lutea on uterine motility. Am. F. Physiol. 102, 39-55.

Senior, B.E. \& Gunningham, F.J. (1974) Oestradiol and luteinizing hormone during the ovulatory cycle of the hen. 7. Endocr. 60, 201-202. 